\title{
Relay-Intercropping Muskmelons with Scotch Pine Christmas Trees Using Plastic Mulch and Drip Irrigation
}

\author{
W.J. Lamont ${ }^{1}$, D.L. Hensley ${ }^{2}$, S. Wiest ${ }^{3}$, and R.E. Gaussoin ${ }^{4}$ \\ Department of Horticulture, Forestry, and Recreational Resources, Kansas \\ State University, Manhattan, KS 66506
}

Additional index words. Cucumis melo, Pinus sylvestris, plasticulture

\begin{abstract}
Two systems of relay-intercropping muskmelons (Cucumis melo L.) with Scotch pine (Pinus sylvestris L.) Christmas trees using black plastic mulch and drip irrigation were evaluated for their potential to improve cash return. Returns ranged from a high of $\$ 26,200 / \mathrm{ha}$ for plastic mulch-drip irrigation and a selling price of $\$ 1.00 / \mathrm{melon}$ to a low of $\$ 6900 / \mathrm{ha}$ for bare ground-drip irrigation and a selling price of $\$ \mathbf{\$ 0 . 4 0} / \mathrm{melon}$. The benefitcost index ranged from 24 to 3.4, depending on the system evaluated. Pine growth apparently was impeded by plastic mulch; however, increased yields of melons grown under plastic mulch may offset the slight decrease in pine growth.
\end{abstract}

Christmas tree production is a common enterprise in many parts of the United States, especially in the northeastern and Great Lakes regions (Chapman and Wray, 1979; Dickson and Winch, 1976). Consumers generally prefer to purchase locally grown trees (Hildebrandt et al., 1989). In many instances, Christmas tree production is relegated to marginal land, and few additional inputs are used. It may take 6 to IO years to produce a marketable 1.8- to 2.4m-tall Scotch pine Christmas tree (Behlen, 1978; Davenport and Walters, 1970). Producers receive no cash return from their investments during this time.

Cut-your-own Christmas trees may be a component of a large retail horticultural operation, especially near urban or suburban populationcenters. Producing such along-term crop on high-value land requires a steady cash flow to ensure a profitable operation. The purpose of this study was to determine if an intensive crop production system using plastic mulches, drip irrigation, and relay-intercropped muskmelons would be feasible for Christmas tree enterprises in areas of limited or highvalue land.

Relay intercropping is the practice of growing two or more crops simultaneously during part of the life cycle of each, A second

Received for publication 20 July 1992. Accepted for publication 3 Nov. 1992. Contribution no. 92-667-J from the Kansas Agricultural Experiment Station (KAES), Manhattan. Mention of a trademark or proprietary product does not constitute a guarantee or warranty of the product by the KAES and does not imply its approval to the exclusion of other products that may be suitable. The cost of publishing this paper was defrayed in part by the payment of page charges. Under postal regulations, this paper therefore must be hereby marked advertisement solely to indicate this fact.

'Assistant Professor.

${ }^{2}$ Associate Professor; Dept. of Horticulture, Univ. of Hawaii, Honolulu, HI 96822

${ }^{3}$ Associate Professor.

${ }^{4}$ Assistant Professor; Dept. of Horticulture, Univ. of Nebraska, Lincoln, NE 68583. crop is planted after the first crop has reached its reproductive stage, but before it is harvested (Andrews and Kassam, 1977). This practice is commonly associated with agronomic crops, such as soybeans, which are planted into winter wheat or spring oats (Chan et al., 1980).

The design was a randomized complete block with four treatments and four replications. Scotch pines were grown with plastic mulch and drip irrigation 1) with and 2) without relay-intercropped muskmelons, 3) with drip irrigation on nonmulched (bare) ground with relay-intercropped muskmelons, and 4) on bare ground without drip irrigation or muskmelons.

The experiment was conducted at the Kansas State Univ. Horticulture Farm near Manhattan. The soil at the site was a Haynie very fine sandy loam. On 2 May 1990, the soil was disked and prepared for bedding before the plastic mulch $(31 \mu \mathrm{m}$ thick, $1.2 \mathrm{~m}$ wide, black, embossed) and drip irrigation tape (0.20 $\mathrm{mm}$ thick, 30-cm emission spacing, 1.5liters $\mathrm{min}^{-1}$ flow rate at $55 \mathrm{kPa}$; Roberts Irrigation Products, San Marcos, Calif.) was applied using standard commercial practices.

Each plot consisted of three, 9.1-m-long rows on 1.5-m centers. Bare-root Scotch pine seedlings were hand-planted $1.8 \mathrm{~m}$ apart on 7 May 1990. 'Legend' muskmelon transplants, grown in a greenhouse in 24- $\mathrm{cm}^{3}$ cells for 4 weeks, were transplanted $61 \mathrm{~cm}$ apart between the pines on 16 May 1990 and 1 July 1991. Fertilizer was applied weekly via the drip irrigation system during the melon-growing

Table 1. Production of muskmelons relay-intercropped with Christmas trees.

\begin{tabular}{|c|c|c|c|c|c|c|}
\hline \multirow[b]{3}{*}{ Treatment } & \multicolumn{6}{|c|}{ Muskmelon yield/ha } \\
\hline & \multicolumn{3}{|c|}{1990} & \multicolumn{3}{|c|}{1991} \\
\hline & No. & $\begin{array}{c}\mathrm{Wt} \\
(\mathrm{kg})\end{array}$ & $\begin{array}{c}\text { Wt/fruit } \\
(\mathrm{kg})\end{array}$ & No. & $\begin{array}{c}\mathrm{Wt} \\
(\mathrm{kg})\end{array}$ & $\begin{array}{c}\text { Wt/frui } \\
(\mathrm{kg})\end{array}$ \\
\hline$\overline{\text { Black plastic mulch and drip irrigation }}$ & 27,700 & 72,000 & 2.6 & 27,400 & 75,400 & 2.7 \\
\hline Bare ground and drip irrigation & 21,500 & 53,800 & 2.5 & 20,300 & 51,300 & 2.5 \\
\hline $\operatorname{LSD}(0.05)$ & NS & NS & NS & 7,011 & 18,903 & NS \\
\hline
\end{tabular}

"Nonsignificant. season $(\approx 12$ weeks $)$ at a total of $95 \mathrm{~N}-0 \mathrm{P}-$ 100K $\left(\mathrm{kg} \cdot \mathrm{ha}^{-1}\right)$. On 28 May 1991, Scotch pine plots without drip irrigation or melons received 7.3N-7.3P-7.3K (kg.ha- $\left.{ }^{-1}\right)$. Soil water status was measured with tensiometers in each treatment 15 and $30 \mathrm{~cm}$ deep, and drip irrigation was applied when soil water potential at $15 \mathrm{~cm}$ reached $-0.25 \mathrm{kPa}$ in the plastic mulchcovered plots. Weeds were controlled in nonmulched plots and aisles with recommended and labeled herbicides.

Melons were harvested nine times beginning 8 Aug. and ending 10 Sept. 1990, and 14 times beginning 26 Aug. and ending 27 Sept. 199 1. Weight and number of marketable fruit were recorded. Scotch pine heights were measured at planting, 20 Sept. 1990, and 22 Oct. 1991. Analysis of variance for subsequent pine heights used height at planting as a covariate. Relative growth of each tree was calculated as height growth divided by initial height for each year and adjusted for height at planting.

The number and total weight of muskmelons were significantly different only in 1991 for those melons relay-intercropped on black plastic mulch with drip irrigation and for those relayed-intercropped on bare ground with drip irrigation (Table 1). Yield in 1990 was similar to that in 1991 , but none of the differences was significant. The weight per fruit was not significantly different for either season. These findings agree with other studies investigating the influence of mulches on muskmelon yield (Berle et al., 1988; Bonanno and Lamont, 1987; Loy and Wells, 1975; Schales and Sheldrake, 1965).

Using the yield data for 1990 and 1991, a partial economic analysis for the relay-intercropped muskmelon system was developed (Table 2) for two selling prices per melon: $\$ 0.40$ wholesale and $\$ 1.00$ retail. Growers located near urban-suburban areas can sell large, eastern-type muskmelons such as 'Legend' at a retail price of $\$ 1.00$, or even more. A partial economic analysis considers only those factors thought to be influenced by the change in cropping system (Berle et al., 1988). From the partial analysis, benefit-cost index values can be calculated assuming $100 \%$ sale of harvested muskmelons (Estes et al., 1985). The benefit-cost index indicates the dollars gained from each dollar invested. For this study, the highest benefit-cost index for the first season (15.0) was obtained by using bare ground with drip irrigation and retailing the melons (Table 2). However, the highest benefit-cost index for the second season (24.0) was obtained by using black plastic mulch with drip irrigation and retailing the melons (Table 2 ). 
Table 2. Partial budget summary (dollars/hectare) for relay-intercropped muskmelons compared with monocropped Scotch pines in Kansas.

\begin{tabular}{|c|c|c|c|c|c|c|c|c|}
\hline \multirow{3}{*}{$\begin{array}{l}\text { Comparison with } \\
\text { monocropped } \\
\text { pine }\end{array}$} & \multicolumn{4}{|c|}{$\begin{array}{l}\text { Kelay intercrop } \\
\text { black plastic/ } \\
\text { drip irrigation }\end{array}$} & \multicolumn{4}{|c|}{$\begin{array}{l}\text { Kelay intercrop } \\
\text { bare ground/ } \\
\text { drip irrigation }\end{array}$} \\
\hline & \multicolumn{2}{|c|}{$\$ 0.40 /$ melon $^{2}$} & \multicolumn{2}{|c|}{$\$ 1.00 / \mathrm{melon}^{2}$} & \multicolumn{2}{|c|}{$\$ 0.40 /$ melon } & \multicolumn{2}{|c|}{$\$ 1.00 /$ melon } \\
\hline & 1990 & 1991 & 1990 & 1991 & 1990 & 1991 & 1990 & 1991 \\
\hline Added revenue & 11,080 & 10,960 & 27,700 & 27,390 & 8,610 & 8,110 & 21,520 & 20,280 \\
\hline Added $\cos ^{y}$ & 3,260 & 1,550 & 2,840 & 1,140 & 1,750 & 1,230 & 1,430 & 930 \\
\hline Net gain & 7,820 & 9,410 & 24,860 & 26,250 & 6,860 & 6,880 & 20,090 & 19,350 \\
\hline $\begin{array}{l}\text { Benefit-cost } \\
\text { index } x^{x}\end{array}$ & 3.4 & 7.1 & 9.7 & 24.0 & 4.9 & 6.6 & 15.0 & 21.9 \\
\hline
\end{tabular}

${ }^{2}$ Wholesale ( $\$ 0.40 /$ melon) and retail $(\$ 1.00 /$ melon) prices for melons.

${ }^{y}$ Cost including the following components when appropriate: plastic, $\$ 1227$; drip irrigation, $\$ 465$; plants, $\$ 145$; fertilizer, $\$ 172$; harvesting costs, $\$ 0.03 /$ melon; packing costs, $\$ 0.015 /$ melon.

${ }^{\times}$Benefit-cost index was calculated as (added revenue)/(added cost).

Table 3. Height and relative growth of Scotch pine grown as a relay intercrop with muskmelons.

\begin{tabular}{lcc}
\hline & & Relative growth \\
\cline { 2 - 3 } Treatment & 22 Oct. 1991 & 1991 \\
\hline Plastic mulch irrigated with melons & $37.4 \mathrm{~b}^{\mathrm{z}}$ & $1.24 \mathrm{bc}$ \\
Plastic mulch irrigated without melons & $37.1 \mathrm{~b}$ & $1.21 \mathrm{c}$ \\
Bare ground irrigated with melons & $42.2 \mathrm{a}$ & $1.45 \mathrm{a}$ \\
Bare ground without irrigation or melons & $41.0 \mathrm{a}$ & $1.32 \mathrm{~b}$ \\
\hline
\end{tabular}

${ }^{\mathrm{z}}$ Mean separation in columns by Tukey's HSD, $\bar{P}=0.05$.

Plastic mulch or relay intercropping with melon had no significant effects on height $(30.4$ to $31.5 \mathrm{~cm})$ or relative growth $(1.35$ to $1.38 \mathrm{~cm})$ of Scotch pine during the first year. Pine survival was not influenced by plastic mulch, drip irrigation, or relay-intercropped melons (data not shown). During the second season after planting, however, those pines grown without plastic mulch were significantly taller than those with mulch (Table 3). Neither melons nor drip irrigation influenced tree growth in bare ground. Relative growth was also highest for pines in bare ground. No observable differences occurred in tree quality, form, or color with any treatment.

The pines were influenced negatively by the plastic mulch with the drip irrigation, but the presence of melons had no impact. This reduced growth may have been due to increased soil temperatures beneath the plastic. Although soil temperatures were not measured in this study, increased temperatures under black embossed mulches (Ham et al., 1991; Mahrer et al., 1984) have been documented. Another factor may be that drip irrigation and plastic mulch resulted in unfavorable soil water $\times \mathrm{O}_{2}$ interactions for the pine; that is, the pines may have been too wet. Scotch pine is a dryland species, and increasing irrigation and maximizing soil moisture conservation to benefit the annual melon crop may have resulted in more water than necessary for optimum pine growth. Pines grown with irrigation and melons, but without plastic, had the highest relative growth and were significantly taller than those with irrigation and plastic.

These results indicate that Scotch pine grown for Christmas trees can be relay-intercropped successfully with muskmelons to provide a significant annual cash flow. This intensive production system allows efficient use of land and other resources. Although the benefit-cost index was similar between treatments with and without plastic mulch (Table 2), the actual dollars returned per hectare should be considered along with other benefits, such as earliness of production (not shown), weed control, and produce cleanliness. Even though the plastic seemed to have some detrimental effects on pine growth (Table 3), the optimum relay-intercropping method tested was with plastic mulch and drip irrigation. Additional work is needed to delineate the reasons for impeded pine growth with plastic mulch and possibly further optimize the cropping system.

\section{Literature Cited}

Andrews, D.J. and A.H. Kassam. 1977. The importance of multiple cropping in increasing world food supplies. Amer. Soc. Agron. Special Publ. 27:1-10.

Behlen, D. 1978. All about Christmas trees. Amer. For. 84(11):36-39.

Berle,D.,E.A.Estes,D.C. Sanders, and W.J. Lamont. 1988. Economic evaluation of different cultural systems for muskmelon production. HortScience 23:324-326.

Bonanno, A.R. and W.J. Lamont. 1987. Effect of polyethylene mulches, irrigation method, and row covers on soil and air temperature and yield ofmuskmelon. J. Amer. Soc. Hort. Sci. 112:735738.

Chan, L.M., R.R. Johnson, and C.M. Brown. 1980. Relay intercropping soybeans into winter wheat and spring oats. Agron. J. 72:35-39.

Chapman, A.G. and R.D. Wray. 1979. Christmas trees for pleasure and profit. 2nd ed. Rutgers Univ. Press; New Brunswick, N.J.

Davenport, O.M. and R.W. Walters. 1970. Christmas tree culture in Kentucky. Agr. Expt. Sta., Univ. of Kentucky, Lexington, Misc. Publ. 346.

Dickson, A. and F.E. Winch, Jr. 1976. Christmas tree production and marketing. Cornell Univ., Ithaca, N.Y., Ext. Info. Bul. 103.

Estes, E.A., W.A. Skroch, T.R. Konsler, P.B. Shoemaker, and K.A. Sorenson. 1985. Net economic value comparisons for eight alternative soil management practices used in stake tomato production. J. Amer. Soc. Hort. Sci. 100:812-816.

Ham, J.M., G.J. Kluitenberg, and W.J. Lamont. 1991 . Potential impact of plastic mulches on the above ground plant environment. Proc. 23rd Natl. Agr. Plastics Congr. p. 63-69.

Hildebrandt, R., W. Loucks, and D. Erickson. 1989. Marketing Christmas trees in Kansas: Consumers' purchasing habits. Agr. Expt. Sta., Kansas State Univ., Manhattan, Rpt. Prog. 579.

Loy, J.B. and O.S. Wells. 1975. Response of hybrid muskmelons to polyethylene row covers and black polyethylene mulch. ScientiaHort. 3:223230.

Mahrer, Y., O. Naot, E. Rawitz, and J. Katan. 1984 Temperature and moisture regimes in soils mulched with transparent polyethylene. Soil Sci. Soc. Amer. J. 48:362-367.

Schales, F.D. and R. Sheldrake. 1965. Mulch effects on soil conditions and muskmelon response. Proc. Amer. Soc. Hort. Sci. 88:425-480. 